\title{
The Last Man: The mutilation of William Lanne in 1869 and its aftermath
}

\author{
Stefan Petrow
}

Regarding the story of King Billy's Head, there are so many versions of it that it might be as well if you sent the correct details. ${ }^{1}$

In 1869 William Lanne, the last 'full-blooded' Tasmanian Aboriginal male, died. ${ }^{2}$ Lying in the Hobart Town General Hospital, his dead body was mutilated by scientists competing for the right to secure the skeleton. The first mutilation by Dr. William Lodewyk Crowther removed Lanne's head. The second mutilation by Dr. George Stokell and others removed Lanne's hands and feet. After Lanne's burial, Stokell and his colleagues removed Lanne's body from his grave before Crowther and his party could do the same. Lanne's skull and body were never reunited. They were guarded jealously by the respective mutilators in the interests of science. By donating Lanne's skeleton, Crowther wanted to curry favour with the prestigious Royal College of Surgeons in London, while Stokell, anxious to retain his position as house-surgeon at the general hospital, wanted to cultivate good relations with the powerful men associated with the Royal Society of Tasmania. But, perhaps because of the scandal associated with the mutilation, no scientific study of Lanne's skull or skeleton was ever published or, as far as we know, even attempted. It seems that Lanne was mutilated to satisfy the egos and 'personal ambition' of desperate men, who wanted a memento of Tasmania's last man, as the newspapers of the time called him. ${ }^{3}$

Unsurprisingly, the Lanne affair has held an enduring fascination for scholars of Tasmanian history. ${ }^{4}$ Lanne's mutilation symbolised the dispossession of land from the Tasmanian Aboriginals and its carving up by racially intolerant and violent white settlers, generally indifferent to the rights of the indigenous population. Furthermore, it illustrated the hegemony scientific knowledge sought to establish over fundamental

1. UT, W9/C1/9 (7), James Backhouse Walker Papers, Ling Roth to Walker, 3 June 1896.

2. Ryan 1981, p. 214.

3. Turnbull 1994, p. 19 rightly claims that 'personal ambition' could be 'as strong a motive for the procurement of remains as the desire to further scientific knowledge'.

4. Bolger 1973, pp. 181-2; Bonwick 1870, pp. 393-400; Cove 1995, pp. 47-9; Ellis 1976, pp. 115-25; Murray 1993, pp.514-16; Ryan 1981, pp. 214-17. 
human rights such as a decent burial, even for a member of a supposedly inferior people, who was officially categorised as a Protestant.

However distinguished some of the work, no single writer has examined the Lanne affair in its full complexity. All writers have relied on a handful of sources and in particular the account of one newspaper, the Hobart Town Mercury. There are at least two problems with this approach which justify a study of the Lanne affair. First, the Mercury has been uncritically accepted as the voice of public opinion. The Mercury reflected the essentially conservative and idiosyncratic opinions of its owner John Davies, the ex-convict and member of the House of Assembly. But in 1869 some nine other newspapers were published in Tasmania and all had something to say about Lanne's death. In some cases, the editorial view followed the Mercury's line of demonising Crowther as the main offender. Other newspapers, however, supported Crowther and directed acerbic comments at Stokell and his supporters in the Royal Society of Tasmania. All the papers published many letters from readers and thus provide us with a more varied response than can be gained from reading the editorials and help us to penetrate the thicket of innuendo, rumour, and allegation that surrounded the affair.

The second problem with accounts of the Lanne affair is the tendency to recount, following the Mercury, the events surrounding the mutilation of his body and the desecration of his grave as simply a story of scandal. This article will widen the angle of vision and consider in more detail the following issues raised by Lanne's mutilation. One issue, given inadequate attention in previous writing, was the extent to which Tasmanians at the time reflected on the guilt and shame of the past treatment of Aboriginals. But arguably anger at Lanne's indignity had little to do with his Aboriginality or his status as the last 'full-blooded' male Aboriginal. After spending his early years in the company of Aboriginal people, Lanne ultimately decided to adapt to white society and in particular the whaling community of Hobart Town. Tasmanians were therefore concerned that what happened to Lanne as a resident of Hobart Town could happen to them. They strongly reacted to the unregulated and indiscriminate dissection of bodies in the hospital. In fact, the head of a dead whiteman had been decapitated and substituted for Lanne's. Public criticism of the management of the hospital resulted in Tasmania's first Anatomy Act being passed in 1869 to provide some protection for dead bodies. They denounced the practice of body-snatching and asserted the right of everyone to be buried without the fear of later interference with their grave. They questioned whether scientists, however important the reason, were justified in flouting the law and the moral standards of the community. Important as these reactions were, perhaps the crucial dimension of the Lanne affair was political. Lanne's mutilation made such a great impact on society, not because he was the so-called 'last man', but because of the political situation in $1869 .{ }^{5}$ William Crowther was a political opponent of the Dry Government, which used Lanne's mutilation as an excuse to discredit Crowther. In many ways, the most interesting point is how Crowther struggled to avoid the Dry Government's attempts to punish him politically and professionally for mutilating Lanne and what these struggles tell us about the morality of public men in this period. But

5. Governor Du Cane wrote of the 'very considerable excitement' throughout Tasmania, Archives Office of Tasmania (AOT), Letterbooks of Confidential Despatches sent to the Secretary of State, Governor's Office 27/1, Du Cane to Secretary of State, 21 April 1869. 
Crowther was a scientist as well as a politician and his commitment to science impelled him to mutilate Lanne's body. Why were scientists interested in Aboriginal skeletons?

Spirited debates by ethnologists, comparative anatomists, archaeologists, and others on the origins of the human race occurred in Britain in the first half of the nineteenth century. ${ }^{6}$ Dividing people into races and studying their physical similarities (and differences) became a popular field of study. From these studies it was thought possible to rank the races, to draw conclusions about their chances of survival, and to establish how close some races were to animals. Remote and so-called inferior peoples, such as the Tasmanian Aboriginals, attracted growing interest. Thomas Malthus identified the Tasmanian Aboriginals as second from 'the bottom of the scale of human beings' ${ }^{7}$ Scientific theories nourished 'a racist ideology' that purportedly explained the superiority of Europeans over the indigenous population, which, because of its moral and intellectual inferiority, was on its way to extinction. ${ }^{8}$ When Europeans settled in Van Diemen's Land in 1803 between 5,000 to 7,000 Aboriginals were living there. ${ }^{9}$ The census of 31 December 1861 recorded the existence of two males and six females, although 'a considerable number of half-castes' lived in the Bass Strait islands off the northern coast of Tasmania. ${ }^{10}$ For the purposes of racial science, 'half-castes' were useless and were ignored. Racial scientists required 'bodies, or parts of bodies, in a fit condition' and of 'high racial purity' to underpin 'the certainty of their findings' ${ }^{11}$

After Charles Darwin published The Origin of the Species in 1859, we find 'a remarkable upsurge of interest in the morphological and anatomical investigation' of the Australian and Tasmanian Aboriginals in an effort to discover vital evidence for comprehending human evolution. ${ }^{12}$ As there was 'immense prestige to be won by contributing to original knowledge in the field of human evolution', Aboriginal bodies were much sought after. ${ }^{13}$ Of all the body parts of interest to scientists from the early nineteenth century, the most crucial was the skull, which was measured to show that Tasmanian Aboriginals had 'smaller, less developed brains' than other peoples and proved that they were 'the missing link between ape and man'. ${ }^{14}$ Indeed, in 1863 T.H. Huxley, Darwin's close friend, referred to Aboriginal skulls as proof of Darwin's theory of evolution.

Such confident pronouncements were based on the relatively few skulls housed in British museums and scientists were anxious to acquire more specimens. ${ }^{15}$ In 1861 the Colonial Secretary, the Duke of Newcastle, wrote to the Tasmanian Governor, T. Gore Browne, asking him to obtain for the Ethnological Society of Oxford a skull of a male and female Aboriginal native. ${ }^{16}$ Newcasle only wanted the skulls provided Gore

6. The complex history of this period and earlier is best approached by reading Stocking 1987; see also Reynolds 1987, pp. 111-129 and Turnbull 1994, pp. 5-20.

7. Cove 1995, p. 45.

8. Ryan 1985, p. 49.

9. Reynolds 1995, p. 4.

10. Examiner, 21 January 1864; Ryan 1981 for 'half-castes'.

11. Turnbull 1991, p. 110.

12. ibid, p. 109.

13. ibid.

14. Reynolds 1987, p. 117; Ryan 1981, p. 214.

15. Plomley 1962. 
Browne could find them 'with propriety' and 'without injuring in any way the feelings of the few Aboriginal inhabitants who still survive'. In 1863 Gore Browne sent Newcastle a skull of indeterminate sex. ${ }^{17}$ He noted that there was 'no difficulty in procuring skulls, but, owing to the mixture in the burial places', it was extremely difficult to say with certainty that the skulls belonged to Tasmanian Aboriginals. 'Several gentlemen', he continued, 'have promised to exert themselves to obtain specimens for me'. Their task was not easy. As one collector noted in 1874, Tasmanian Aboriginal skulls were 'rare objects' and were not held in anything like abundance'. ${ }^{18}$ Tribal custom was important here. Some tribes placed skulls in holes in the ground and covered them with leaves and dirt; other tribes burnt their dead and thereby contributed to the scarcity of skeletons. ${ }^{19}$ In the late 1860 s the rarity of Aboriginal skeletons, 'the application of evolutionary principles to human history', and William Lanne's status as the last 'fullblooded' Tasmanian Aboriginal male gave his death much greater significance to the scientific community than his life ever had. ${ }^{20}$

\section{William Lanne 1835-1869}

One of five children, William Lanne (sometimes called Lanny or Lanney) was born at Coal River in about $1835 .{ }^{21}$ In 1842 Lanne's family was taken from the west coast to the Aboriginal settlement at Flinders Island. After many died of disease, the remaining 44 Aboriginals were moved to Oyster Cove, south of Hobart Town, and Lanne was admitted to the Queen's Orphan Asylum on 28 December 1847. Here he was 'partly educated'. According to one account, he wrote 'a fair hand', 'read well', and was 'said to be intelligent'. Lanne received some religious teaching and was designated a Protestant. In January 1853 Lanne was apprenticed to William Rumney, a farmer at Clarence Plains, on the eastern side of the River Derwent.

How long he stayed with Rumney is uncertain but he eventually found his way to Oyster Cove. While living at Oyster Cove, Lanne was regularly taken out on whalers and 'acquired a partiality for a sea-faring life'.22 Aboriginals were valued by whaling masters for their 'great power of vision' and were employed as mast-headsmen. Lanne sailed with the Aladdin and later the Runnymede. To his fellow sailors, Lanne was known as 'King Billy': he was popular, being regarded as 'a good natured, jolly fellow, and an amusing companion'. The Mercury described Lanne as 'a bluff young gentleman', whose favourite topics of conversation were the rations he received from the government, 'boating amusements', and 'sundry outdoor healthful occupations'. ${ }^{23}$ Some contemporaries painted a less ebullient picture. Doctor Joseph Milligan, 'the last Protector' at Oyster Cove, thought Lanne was a 'very docile boy and youth' and was 'stupid and

16. Australian Joint Copying Project, Colonial Office series, CO/280/358/5032, Newcastle to Gore Browne, 26 December 1861.

17. ibid., Gore Browne to Newcastle, 20 March 1863.

18. Davis 1874, pp. 4-5.

19. Barnard 1890, p. 606.

20. Reynolds 1995, p. 202.

21. Mercury $(M), 13$ November 1866, 5 March 1869; AOTSWD 28, Register of children admitted and discharged from the male and female Orphan School 1828-1863, p. 23 boys; AOT Correspondence file on William Rumney; Bonwick 1870, pp. 283-4 393-5.

22. ibid.

23. $M, 13$ November 1866,12 July 1867 . 
dull of apprehension'. ${ }^{24}$ Attempts to teach him religious principles were 'a signal failure'. These different perceptions can be reconciled. No doubt Lanne felt comfortable and happy with his sailing companions but was less inclined to communicate or co-operate with the authorities, who had presided over the decline of his people.

Views differed on other matters. According to one account, Lanne was 'not particularly proud of his ancestry'. ${ }^{25}$ The evidence for this view is slight. When his portrait was taken by Charles Woolley for the Intercolonial Exhibition in 1866, Lanne disliked the photograph, intimating that it was 'too black for him'. Other evidence indicates that he was proud of his Aboriginality. In 1864, after complaining that rations for the settlement were too low, Lanne told Colonial Treasurer Charles Meredith that 'I am the last man of my race, and I must look after my people' ${ }^{26}$ Lanne was very popular with the Aborig-

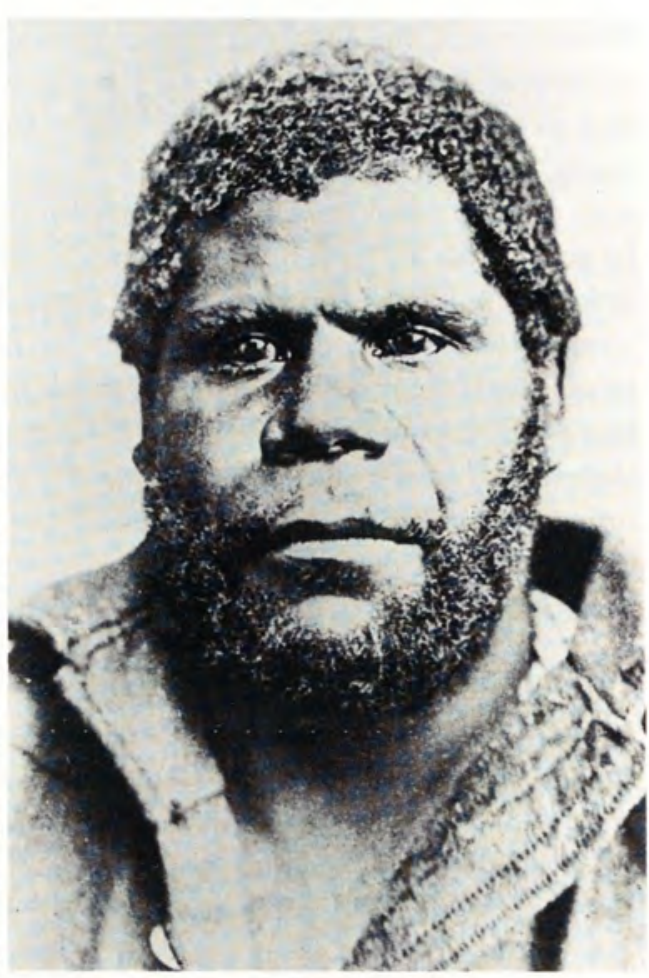

William Lanne. Photograph reproduced courtesy of the Archives Office of Tasmania inal women at Oyster Cove, who described him as a "'fine young man-plenty beard-plenty laugh-very good, that fellow"',27

Apparently Lanne believed himself 'every inch a king' and sought out English royalty. In November 1866, before leaving for England, Lanne said he hoped to have an audience with Queen Victoria, although we do not know whether this desire was fulfilled. ${ }^{28}$ In January 1868 Lanne, dressed in 'a blue suit with a gold lace band round his cap', attended the Hobart Town Regatta to meet the Duke of Edinburgh, who received him with 'kindly consideration'. Lanne did not produce any children. Unlike most whalemen, he did marry, becoming the fourth 'husband' of Truganini, a much older Aboriginal woman. ${ }^{29}$ Despite his links with the remaining Aboriginals, Lanne probably felt more comfortable at sea and carousing in pubs with his sailing companions than living at Oyster Cove.

24. Bonwick 1870, p. 394

25. M, 5 March 1869 .

26. AOT Colonial Secretary' Department (CSD) 4/77/231, Meredith to Tarleton, 5 December 1864.

27. Bonwick 1870, pp. 186-7.

28. $M, 13$ November 1866 .

29. Agnew 1888, p. 479; Ellis 1976, p. 116 says Lanne was the third husband. 
On 4 March 1868 Lanne boarded the Runnymede for a long voyage. ${ }^{30}$ He returned 'fat and unhealthy' in February 1869. After receiving his wages, Lanne lodged at the Dog and Partridge public-house, a popular haunt for whalers, prostitutes, and other low-class Hobartians. ${ }^{31}$ There Lanne enfeebled his constitution by indulging his propensity for beer and rum. He fell ill and was supplied with medicine from Dr. Thomas Smart's dispensary. After a week, he contracted choleraic diarrhoea and received medical treatment for another week. On 3 March, while dressing to go to hospital, Lanne died. ${ }^{32}$ As an honorary medical officer at the General Hospital, Dr. Crowther obtained a coroner's order and sent the body to that institution's dead-house.

\section{Mutilators and body-snatchers}

William Crowther had long been desperate to obtain an Aboriginal skeleton to send to Sir William Flowers, curator of the Royal College of Surgeons' Hunterian Museum. Crowther co-owned land adjoining the Oyster Cove settlement. ${ }^{33}$ In 1862 his co-owner Henry Harrison Pybus offered to take responsibility for the Aboriginals at Oyster Cove for $£ 500$ and to look after them on his property. This would have given Crowther 'prime access to the bones and skulls he so coveted' but the government refused, thinking $€ 500$ too much. Lanne's death provided Crowther with his last opportunity and he asked the Premier and Colonial Secretary Richard Dry for the skeleton. ${ }^{34}$ A member of the Royal Society Council, Morton Allport, had already contacted Dry with the same request.

In October 1866 Crowther had topped the poll for the seat of Hobart Town but resigned from parliament when Dry refused to include him in the ministry. Perhaps trying to win back an acidulous political opponent, Dry now graciously put it to the Royal Society Council that 'you may find it not incompatible with the interests of our local Institution to waive your claim' to Lanne's skeleton in Crowther's favour. ${ }^{35}$ However, the Royal Society, which had close links with government and received an annual government grant of $£ 5,000$, asserted that its right to the skeleton of the last male Aboriginal' of Tasmania was 'altogether paramount to that of any other scientific institution in the world' ${ }^{36}$ Dry apparently inclined to the Royal Society's view that 'discredit' would attach to any government which allowed 'so essential an element of a national collection to be lost to the country'. Dry probably felt that further offending Crowther by denying his request was less of a political risk than giving Lanne's skeleton to the Royal College of Surgeons and offending the Royal Society. But the Royal Society admitted 'the claims which science in general has upon these valuable relics'. It intended to photograph the skeleton 'on a large scale' and present copies to the museum of the Royal College of Surgeons and other interested institutions. Casts of 'specially interesting'

30. M, 5 March 1869.

31. Chamberlain 1988, p. 240; Critic, 5 October 1923.

32. M, 4, 27 March 1869; soon after his death, a licensee sought payment for ale and rum that Lanne had owed him since 1866 see AOTCSD 7/24/150.

33. Pybus 1992, pp. 166-8.

34. UT RSA/A/4, 174-5, Crowther to Dry, 4 March 1869, Dry to Royal Society Council, 4 March 1869; State Library of Tasmania, Allport Library, Morton Allport papers, Letterbook 18681871, Allport to Dowdell, 20 April 1869; Rimmer 1981, p. 97.

35. ibid.

36. AOTCSD 7/23/127, Agnew to Dry, 5 March 1869. 
parts of the skeleton would also be provided. This was a strong assertion of authority by the oldest colonial scientific body against its metropolitan counterpart, represented in Hobart Town by the overblown arrogance of William Crowther. ${ }^{37}$ But whatever his inclinations, Dry was a deeply religious man and wanted to ensure that Lanne first received a Christian burial before countenancing the Royal Society's request. Dry assured Crowther that if an opportunity arose while he was in government to secure a skeleton for the Royal College of Surgeons from 'the graves of Aboriginals without violating the feelings of individuals or of the community', he would place 'no impediment' in Crowther's way. ${ }^{38}$

Aware of the anxiety of Crowther and the Royal Society to secure an Aboriginal skeleton, on 4 March Dry instructed Dr. George Stokell, the recently-appointed house surgeon, not to permit 'any mutilation' of Lanne's body. ${ }^{39}$ After telling the steward and storekeeper Charles Seager and the attendant James Weare of Dry's instructions, Stokell met Crowther in the street. ${ }^{40}$ Crowther told Stokell that Dry had 'given' him Lanne's body and he intended to have it. Stokell countered with Dry's instructions that the body should not be touched or mutilated. Crowther then invited Stokell to his house. Stokell foolishly accepted this transparently suspicious invitation and arrived at the agreed time of 8.00 p.m. Crowther was absent but his wife 'kept him talking' for some time. Stokell finally left and arrived at the hospital at 9.00 p.m. He discovered that Crowther and his son Bingham had spent nearly an hour at the hospital. Stokell entered the deadhouse to find that Lanne's skull had been removed and had been replaced by the skull of a.white man, whose body had been placed in the adjoining dissecting room.

Remembering Dry's promise to the Royal Society, Stokell told its Secretary, Dr. James Agnew, of the mutilation. ${ }^{41}$ Agnew consulted two other members Morton Allport and J.W. Graves. They decided to prevent the mutilators from getting the rest of Lanne's body by cutting off his hands and feet and hiding them in the Society's museum. It seems that Dry knew nothing of this mutilation, which was against his instructions, and it is unclear when he was told.

Strangely, Dry appears not to have made plans to bury Lanne. This responsibility was undertaken by Captain James Bayley, owner of the Runnymede. At the request of Graves, a well-known friend of the remaining Aboriginals, Lanne's funeral was held at 2.00 p.m. on Saturday 6 March to allow for the attendance of all the colonists who desired 'to assist at the obsequies' and to show 'some outward token of respect' for 'the last male Aboriginal Tasmanian'. 42 Lanne's coffin was covered with a black opossum skin rug as a symbol of the Aboriginal people. ${ }^{43}$ On the rug were placed two native spears and waddies, 'round which were twined the ample folds of a Union Jack, specially provided by the shipmates of the deceased'. Was this supposed to indicate the supremacy of the British over the fierce Aboriginal fighters? If so, it was misplaced

37. MacLeod 1988; Winter 1972.

38. $M, 8$ March 1869 .

39. AOTCSD 7/23/127, Solly to Stokell, 4 March 1869.

40. ibid.

41. M, 8 March 1869; Evening Mail (EM), 12 March 1869.

42. Tasmanian Times (TT), 6 March 1869.

43. M, 8 March 1869. 
symbolism as Lanne was anything but a fighter. Four white lads, who had crewed with Lanne on the Runnymede, carried the coffin. The pall-bearers were Captain Hill of the Runnymede and three 'coloured' seamen-John Bull, a native of the Sandwich Islands, Henry Whalley, a 'half-caste' native of Kangaroo Island, South Australia, and Alexander Davidson, an American. The chief mourners were Captain McArthur of the Aladdin and Captain Bayley. Other mourners included almost all the masters of vessels in port, numerous members of the whaling fraternity, the Mayor James Milne Wilson, many 'old colonists and native born Tasmanians'. As the funeral party moved along Liverpool Street and into Murray Street to St. David's Church, 'it gathered strength, and was followed by a large concourse of spectators'. Reverend F.H. Cox read the church service. Up to 120 mourners left the church for St. David's burial-ground in Davey Street, where Cox read the second part of 'the impressive burial service' of the Church of England.

Word of the mutilation had spread. Indignant at 'so unwarrantable desecration', prominent citizens asked Dry to exhume the body for examination. ${ }^{44}$ Dry proposed that the grave be guarded until Monday morning when an enquiry would proceed and two municipal police constables were so deployed. But late on Saturday night, the police were ordered to leave the graveside and soon after Lanne's body was removed. At 9.00 a.m. on Sunday morning the gravedigger discovered the coffin exposed, a skull lying next to the grave, and blood on the ground. Traces of blood allegedly stopped at the gate opposite the stores of the Anglo-Australian Guano Company in Salamanca Place, in which Crowther had an interest.

At 9.30 a.m. on 8 March, Dry sent for Alfred Kennerley, Chairman of the Hospital Board and a member of the Royal Society Council, and they questioned Seager, Weare, and Dan, the hospital's barber. ${ }^{45}$ All testified to the presence of Crowther and his son in the dead-house between 8.00 p.m. and 9.00 p.m., although they could not say for certain that they were carrying anything as they left. Dry acted on this evidence of Crowther's guilt. He instructed Kennerley to suspend Crowther as an honorary medical officer until he could satisfactorily explain the points raised in the evidence. ${ }^{46}$ Dry also wrote to Crowther, asking him why he had, prima facie, ignored the instructions not to mutilate Lanne's body. The Hospital Board also withdrew permission for Crowther's son to study at the hospital. All the letters written to and by Crowther and the evidence given at the enquiry were published in the newspapers in an attempt to damage Crowther's reputation.

Anxious to find Lanne's body, between 4.00 and 5.00 p.m. on 8 March, Crowther arrived at the hospital gate with his son, Superintendent of Police Richard Propsting, and a number of others. ${ }^{47}$ Crowther forced his way into the hospital and headed for the old infirmary. Stokell arrived and ordered Crowther to leave. Crowther responded by hammering in a panel of one of the wards and forcing the door's lock. Finding 'masses of fat and blood' which he assumed to be Lanne's but no bones, Crowther and his party left. Crowther made no effort to explain his actions but later in a letter to the press accused Stokell of removing Lanne's head. ${ }^{48}$ Rumours began to spread that Lanne had

44. TT, 8 March 1869; AOTCSD 7/23/127, Bayley, McArthur, and Colvin, 6 March 1869.

45. $E M, 8$ March 1869.

46. ibid, 8 March 1869; AOTCSD 7/23/127, Dry to Kennerley, Dry to Crowther, 8 March 1869.

47. $M, 9$ March 1869. 
not been dead but merely in a trance' when his head was removed. ${ }^{49}$ Another rumour claimed a doctor had 'trifled with the skin of the remaining extremity, (the procreative member)'. Without a full and open enquiry, eccentric claims like these were bound to flourish.

As Colonial Secretary, Dry was politically responsible for the General Hospital and he decided to appoint a fuller Board of Inquiry into 'the circumstances attending the mutilation' of Lanne 'with the view of ascertaining when, and by whom, such mutilation was effected' ${ }^{50}$ The chairman was the Recorder of Titles, William Tarleton, who had previously been Police Magistrate of Hobart Town; the other members were the respected old colonists and public-spirited businessmen Charles Colvin and Isaac Wright. Crowther declined to appear before the Board as evidence had 'already been taken and published by the Government ex parte and judgment pronounced against me in the matter'. Stokell testified that Crowther called him 'a fool to suppose that a paltry little place like Tasmania had a better right' to Lanne's body than London. ${ }^{51}$ Stokell denied cutting off the head but admitted removing Lanne's hands and feet. Stokell's weak justification was that, as Dry had given Lanne's body to the Royal Society, he was not acting against Dry's orders.

Dry was determined to keep Crowther on the defensive. To test Crowther's allegation that Stokell was the guilty party, the government prosecuted Stokell for removing Lanne's head. ${ }^{52}$ The case was heard in the Police Court before Mayor Wilson, who was associated with the Dry Government, and not before a Stipendiary Magistrate, who would be more impartial and independent. Crowther was examined by the prosecutor Chief District Constable Alfred Jones and Stokell's defence counsel Solicitor-General R.P. Adams. Crowther conceded little. He wrongly claimed that he had only accused Stokell 'inferentially' not directly. But generally Crowther declined to answer any questions about his role, if any, in the affair on the grounds that he might incriminate himself. The government failed to trick Crowther into admitting his complicity or guilt. But, as no evidence was produced to incriminate Stokell, the Mayor dismissed the case.

Meanwhile, the Board of Inquiry foundered over a difference of opinion. Wright and Colvin wanted to extend the scope of the enquiry to include the circumstances surrounding the removal of the body from the grave, while Chairman Tarleton held that to so do would require the permission of Dry. ${ }^{53}$ When Dry decided not to extend the scope of the enquiry, Colvin and Wright resigned. Satisfied with the evidence taken by Tarleton and given at the Police Court, Dry ended the enquiry. As Crowther had refused to explain why he violated the order not to mutilate Lanne's body and as he tried to induce the public to believe Stokell was responsible, Dry felt justified in dispensing with Crowther's services at the General Hospital. ${ }^{54}$ Crowther refused to be bound by Dry's directions but Dry dismissed his protests. Twelve hundred of Crowther's sup-

48. EM, 10 March 1869.

49. Leader, 12 March 1869.

50. AOTCSD 7/23/127, Dry to Tarleton, Colvin, and Wright, 12 March 1869; EM, 12 March 1869 (emphasis in the original).

51. M, 13 March 1869; EM, 12 March 1869.

52. $M, 16$ March 1869; EM, 15 March 1869.

53. EM, 16 March 1869; AOTCSD 7/23/127, Dry to Tarleton, 17 March 1869.

54. AOTCSD 7/23/127, Dry to Crowther, 3 April 1869, Crowther to Dry, 5 April 1869. 
porters petitioned the government to reinstate him, claiming the evidence was unreliable and that the poor and sick needed his services. ${ }^{55}$ Dry and the Hospital Board stood firm, relenting only to allow Crowther's son to recommence his medical studies if an honorary medical officer was willing to take him as a pupil. ${ }^{56}$

\section{The aftermath of the Lanne affair}

While in itself an interesting if not bizarre episode in Tasmanian history, what happened to Lanne's body does raise wider issues, touching on key institutions, including the hospital, the police, the government, the Royal Society, and the largest urban cemetery, St. David's. It also prompted consideration of moral issues of more relevance to Tasmanians of the late 1860 s than the demise of the Aboriginal population. But the Lanne affair did cause some Tasmanians to reflect on their past and present attitudes to Aboriginals and that issue will be dealt with.

European views on the treatment of Aboriginals had always been 'deeply ambivalent' and such was the case in $1869 .{ }^{57}$ According to the anonymous correspondent to newspapers, 'Job Muggs', a 'large portion of society' still regarded Aboriginals with 'far less consideration than they are accustomed to bestow upon their dogs or cattle'. ${ }^{58}$ Few cared, claimed 'Job Muggs', that Aboriginals had suffered 'robbery, murder, and rape' and numerous other indignities since first settlement. No surprise, then, that the 'shameless atrocity' perpetrated on Lanne's body was viewed by the religious community with 'comparative indifference', while the rest of the population 'merely laughed' at what had happened.

Humour was certainly one response. Ridicule was the theme of poems published in newspapers. ${ }^{59}$ Some enterprising souls tried to cash in on Lanne's death. On 16 April an advertisement announced the display of a complete, full sized bust of Lanne by the artist Franciso Sante, which Hobartians could see for a small sum. ${ }^{60}$ In the storage rooms of Walch and Sons and Birchalls' bookshops 'numerous' busts of Lanne's head produced by Charles Woolley could be found. ${ }^{61}$ In June 1869 advertisements in the Cornwall Chronicle melodramatically contained just the words 'Look Out for KING BILLY'. On 2 July it became clear that the words referred, not to Lanne's resurrection from the dead, but to King Billy Sheepwash Tobacco, a product from Ducroz, Nichols \& Company. ${ }^{62}$ A recent writer has suggested that the title King Billy was a joke, signifying 'a partially domesticated animal who could imitate European behaviour and was harmless and amusing'. ${ }^{63}$ Alternatively, it could be seen as an affectionate nickname and a joke which the good-humoured Lanne shared. The curiosity evoked by the chance of seeing Lanne's skeleton-and not the exhibition of salmon smolts as the organisers

55. ibid; $M, 9$ April 1869.

56. EM, 27 March 1869; M, 22 April 1869.

57. Reynolds 1995, p. 82.

58. Cornwall Chronicle (CC), 12 March 1869, letter by 'Job Muggs'.

59. Leader, 23 and 30 March, 30 July 1869.

60. EM, 16 April 1869.

61. Examiner, 10 April 1869.

62. CC, 2 July 1869.

63. Cove 1995, p. 44. 
claimed-might explain why 12,960 people visited the Royal Society's museum in 1869 , nearly double the number of visitors for any previous year. ${ }^{64}$

Certainly, Tasmanians made more fuss about Lanne after his death than when he was alive, as a Crowther supporter Charles Dowdell noted: 'Did Lanney have a friend while knocking about the streets tipsy; when he travelled wanting? when he died?' 65 Ignored by the government and the Royal Society, Lanne's 'only true friend' was Captain Bayley, "who had put his hand in his pocket, and given the money to bury poor Billy', claimed Dowdell. Bayley, a wealthy man, was certainly not Lanne's only friend, as the number of seamen who attended his funeral showed. ${ }^{66}$ Whalers contained numerous black seamen from all parts of the world and Lanne no doubt did build strong friendships amongst that modestly-paid and close-knit community.

Apart from any respect he might have had for a good seaman or his responsibility as Captain to bury a dead crew member, possible explanations for Bayley's benevolence might be guilt or shame. The Tasmanian Times thought that many colonists 'probably' regretted, 'perhaps with compunction, the extirpation of the original occupants' of Tasmania. ${ }^{67}$ British views on the affair were a consideration. The colonists had already attracted infamy by failing to provide for 'the comfort and protection of these unhappy victims of advancing civilisation'. The Lanne affair 'lowered us at once to the level' of savages and would, thought the Tasmanian Times, attract further opprobrium from 'foreign critics' ${ }^{68}$ At a time when the stigma of being a convict colony was in retreat, publicity over Lanne's body might deter British immigrants from settling in Tasmania.

The Mercury stressed the 'numerous cruelties' that Aboriginals suffered 'at the hands of depraved men' ${ }^{69}$ Not only dispossessed of their land, their children were taken away and their women were 'treated most shamefully by ruffians'. The Leader also expatiated on the Aboriginals 'long tale of suffering and oppression' ${ }^{70}$ Alcohol and tobacco introduced by colonists, squatters and their dogs, 'the lawless and licentious violence' of bushrangers and shepherds, and the guns of convict constables helped destroy the Aboriginal people. Government policy consummated 'the exterminating policy of the early settlers'. Aboriginals were first placed on 'bleak and barren' Flinders Island and then transferred to 'an unhealthy swamp' at Oyster Cove, where they 'died off like rotten sheep'. Thus the government dealt with 'a difficult social problem' and saved much public expenditure. Under this onslaught, the extinction of the Aboriginals was assumed to be inevitable.

Throughout the Lanne affair, no mention was made of the offsprings of sealers and Tasmanian Aboriginal women living in the Bass Strait islands and little thought was given to Lanne's wife Truganini. The Leader did note how 'the feelings of the poor survivors at Oyster Cove have been cruelly wounded' by the indignities to which Lanne's body had been subjected. ${ }^{71}$ Feeling 'very low spirited' since hearing on 13

64. Royal Society of Tasmania Annual Report 1869, 81.

65. TT, 20 April 1869; $M, 20$ April 1869.

66. Chamberlain 1988, pp. 103-4, 327-8.

67. TT, 6 March 1869.

68. ibid, 9 March 1869.

69. M, 5 March 1869 .

70. Leader, 12 March 1869. 
March 1869 of her husband's death, Truganini considered that she had been 'treated cruelly by the authorities' because she had not been allowed to attend Lanne's funeral and believed she should have been given 'a mourning dress'. ${ }^{72}$ When she heard of Lanne's mutilation, she vowed that 'nothing would induce her to become an inmate of the hospital, where she might be treated as he was after death'.

As Tasmania was probably the only place in the world able to 'boast' of burying its last male Aboriginal, Charles Gaylor proposed 'some slight memorial in honour of that eventful occasion'. ${ }^{73}$ If two thousand residents contributed two shillings and sixpence, $£ 250$ could be raised. The response to Gaylor's proposal was mainly positive. A 'Native' thought that more than $£ 250$ could easily be raised to erect an 'historical and substantial record of the demise of the last male aborigine of this enterprising colony ${ }^{\prime}{ }^{74}$ The memorial would show the world that in Tasmania 'not only the last remains of Europeans are respected, but also those of every other creed and country, from the Chinese down to the poor black aborigines'. Put in this way, the memorial might be read as symbolising the triumph of a superior civilisation over a supposedly inferior people. For 'Half Crown', however, the memorial would have a more noble purpose. It would make 'amends for the wrongs our ancestors inflicted' upon Aboriginals and would 'mark their extinction by some public recognition of their former inheritance of this, their own kingly empire'. 75

The other side of this view was expressed by 'KPX', who regarded Gaylor's proposal as 'a grim jest'. ${ }^{76}$ Raising money for a memorial would only draw attention to a scandal that should be 'covered for ever by a veil of oblivion' rather than by 'perpetuating the miserable story by a monument'. Even if Tasmanians built 'the best monument we may, we can only preserve the memory of our disgrace, not atone for it'. Shame prevailed as no monument was built. ${ }^{77}$ For Reynolds, this soul-searching and confessing to the ill-treatment of Aboriginals 'eased the conscience without having any political or economic implications-moral concern was politically safe and provided no legal purchase ${ }^{\prime}{ }^{78}$ This might have been so for the governing and wealthy classes but for other Tasmanians, and especially the humble white folk and 'coloured' seamen with whom Lanne associated, sadness was genuine.

Attendance at Lanne's funeral was one way of showing 'some outward token of respect' for Aboriginals. ${ }^{79}$ It exhibited 'our appreciation of their merits, and our sorrow for their extinction'. As noted above, the funeral service did genuinely honour Lanne and was attended by a cross-section of Tasmanian society. But it raised questions about

71. ibia.

72. Examiner, 3 April 1869; Crowther 1974, p. 22; Agnew 1888, p. 480.

73. EM, 15 March 1869; Gaylor was the Tasmanian-born son of ex-convict and publican Charles Gaylor, see AOT, Correspondence file on Charles Gaylor.

74. ibid, 16 March 1869.

75. TT, 18 March 1869.

76. ibid.

77. In 1911 the idea of a memorial to Aboriginals was raised again, with the suggested location being St. David's Park but nothing eventuated, $M, 21$ November 1911, letter by Reg. H. Meaburn.

78. Reynolds 1995, p. 201.

79. TT, 6 March 1869. 
Lanne's religious beliefs. The Cornwall Chronicle claimed that Lanne died 'in reality a Pagan, although nominally catalogued and placed in the census' as a member of the Church of England. ${ }^{80}$ Like his fellow Aboriginals, Lanne could 'repeat mechanically the name of God, and even the words of a few hymns' but they were not 'ever in the true sense of the word Christians'. In return for taking their land, the colonists did not give Lanne or his people 'the comfort of dying Christians' or 'while living the benefits of practical civilisation'. 'Job Muggs' claimed to have conversed and mingled with the Aboriginals at Oyster Cove and assessed 'the effects upon them of their contact with the civilization of the white man'. 81 He found not 'the smallest indication of any beneficial change having been effected'; attempts 'to christianize these poor heathens' had failed.

But even if Lanne had not been a Christian, few condoned his mutilation or the removal of his body from the grave and the way the graveside had been left by 'two competing parties of resurrectionists' ${ }^{82}$ In England body-snatching for dissection or any other purpose had traditionally aroused intense opposition across classes. ${ }^{83}$ In Tasmania the wilful neglect of cemeteries had attracted public criticism in the 1860 s but 'the desecration' of Lanne's grave raised 'public indignation to no ordinary pitch'. ${ }^{84}$ According to the Mercury, this response showed that 'the common people have a better appreciation of decency and propriety than such of the so-called upper classes and men of education'. Such men had perpetrated 'a flagrant outrage from which the greatest ruffians in Tasmania's worst days would have shrunk'. If the offenders were not punished by the law, they should be socially ostracized 'by making them marked men, targets for the finger of scorn'. The Cornwall Chronicle thought the government should have taken greater precautions to stop 'so foul and barbarous a sacrilege' on Lanne's grave. ${ }^{85}$ The act would have 'a most pernicious influence on the morals of the people'. It will teach citizens to 'treat with contempt' the rites of Christian burial. The consensus was that the offenders should be punished. The Examiner believed that Tasmanians were opposed to the emergence of a 'race of body-snatchers' and supported their 'severest repression'. 86 'Humanitas' told readers of the Tasmanian Times that stealing a body from the grave had 'always been regarded with abhorrence and indignation' in 'all civilised countries' ${ }^{87}$ As the grave had been desecrated, the trustees were obliged to reassure their parishioners that corpses would be safely interred in the future. ${ }^{88}$

The only cleric to make a public statement was Reverend F.H. Cox. He thought 'nothing more loathsome than the mutilation of the unburied corpse of the poor Aboriginal, unless it be the violation of his grave immediately after the rites of Christian burial, and the impunity which has been granted to that profane and indecent act ${ }^{\prime}{ }^{89} \mathrm{He}$ further believed that Crowther deserved 'reprobation' for making 'false accusation' to

80. CC, 10 March 1869 .

81. ibid, 12 March 1869.

82. TT, 22 March 1869 , letter by 'Humanitas'.

83. Richardson 1987, pp. $89,99$.

84. M, 9 March 1869; for the state of cemeteries, see Petrow 1993.

85. CC, 10 March 1869.

86. Examiner, 11 March 1869.

87. TT, 22 March 1869.

88. ibid, 18 March 1869.

89. EM, 10 April 1869. 
protect himself. But Cox was an ally of Crowther's and admired his work for the poor. Espousing 'the gospel of forgiveness', he seemed willing to exonerate Crowther. $\mathrm{He}$ wrote off the whole affair either as defensible in the interests of anatomical science or as a 'hoax' or practical joke redolent of 'medical-student morality' but certainly not 'an unpardonable sin'. Cox exhibited that 'practical tolerance for the idiosyncracies of fellow men' that was 'a product of life in an isolated city'. ${ }^{90}$

Cox's tolerance had its limits, however. He was intent on punishing the bodysnatchers and, with three church-wardens, approached Mayor Wilson. ${ }^{91}$ If body-stealing was illegal, they asked Wilson to proceed against those who stole Lanne's corpse. Wilson replied that body-stealing from a burial-ground was 'not a statutable offence' in Tasmania. He judged that any prosecution at common law.would probably not secure a conviction. In any case, Wilson's duty was to adjudicate cases not to act as a public prosecutor. He noted that a bill would be introduced into parliament next session to regulate the methods for appropriating bodies 'to the purposes of anatomical science'. Apart from the legal difficulties, it was unlikely that the government would prosecute its allies, Stokell and his confreres at the Royal Society. No doubt the government would have liked to prosecute Crowther and his party, who 'recklessly left the grave in an unseemly state, either from disappointment, or to excite indignation against the actual body-snatchers' but this opportunity was not available. ${ }^{92}$

Further enquiry might also force the Dry Government to explain why it asked the much-maligned municipal police to guard the grave and not the territorial police, over which it had control. ${ }^{93}$ The role of the municipal police was questioned. It was alleged that Superintendent Propsting personally discharged the police from the grave at 11.30 p.m. ${ }^{94}$ Those same police, rumour had it, were "shortly afterwards seen in company with the party who carried the body away'. An investigation by the Police Committee of the Hobart Municipal Council found that 'certain' constables had neglected their duty and left their beat without permission. ${ }^{95}$ They were 'admonished, and allowed to return to their duty'. Nothing was said about Propsting's role, although it was generally believed that he had been bribed to order his constables away from the grave. ${ }^{96}$ The independence of the two members of the Police Committee was challenged. ${ }^{97}$ Mayor Wilson had played a dubious part in the affair by presiding over the sham trial at the Police Office, while Alderman David Lewis was an anti-Crowther member of the Hospital Board.

Interestingly, the Tasmanian Times felt that no eyebrows would have been raised if the government and the Royal Society had, with the consent of the trustees, of St. David's burial-ground, 'decently' taken Lanne's body from the grave and placed it in the museum. ${ }^{98}$ This reading of events was surely right. The outrage centred on how the
90. Bolger 1973, p.182.
91. $M, 15$ April 1869.
92. EM, 12 March $1869 ; M, 12$ March 1869.
93. TT, 9 March 1869.
94. EM, 10 March 1869.
95. TT, 7 April 1869.
96. Bolger 1973, p. 181.
97. Leader, 9 April 1869.
98. TT, 2 April 1869. 
body was removed. Few pardoned the scientists' rash action, but there might have been support for eventually letting Lanne's body be preserved in the museum in the interests of posterity. According to the Mercury, the men of science should have embalmed the body and after a decent interval 'raised the bones for preservation' 99 The Mercury wondered whether financial gain was a motive. Some English scientific societies would pay handsomely for Lanne's skeleton and this 'might prove a sufficient solatium for any local obloquy' directed at the culprits. The Examiner thought that the scientists had erred. Lanne had been 'born and bred in civilization' and therefore his skeleton would not be 'the exact type of his race'. ${ }^{100}$ The Examiner suggested that digging up appropriate sites on Flinders Island would supply plenty of skeletons 'to satisfy the scientific societies of Europe if the business was discreetly managed'.

If European scientific societies deserved censure, the role of the Royal Society of Tasmania was not above reproach. The oldest scientific society in Australia, the Royal Society was comprised mainly of gentlemen scientists. ${ }^{101}$ Few members could claim impressive scientific credentials and even fewer had the expertise to provide informed observations on the significance of Lanne's skeleton. But it was true that the Royal Society had taken an interest in the Tasmanian Aboriginals since 1848, when Joseph Milligan became Secretary. The Royal Society then saw it as part of its duty 'to keep a record of the Tasmanian Aborigines'. In 1857 it arranged for a photographer to obtain 'accurate representation of their form, features, and colour, singly or in groups'.

The involvement of the Royal Society in the Lanne affair was defended by its Secretary, Dr. James Agnew, also a member of the Royal College of Surgeons. He held that 'every enlightened individual' would support the Royal Society. ${ }^{102}$ Lanne's skeleton should have been 'preserved to all futurity in our Tasmanian museum' but this was denied by 'the contemptible vanity (if not a baser feeling) of a single individual'. Agnew also defended the decision to cut off Lanne's hands and feet. The skull was 'the most valuable' part of the skeleton and, once it had been taken, removing the hands and feet had not 'the slightest consequence'. The Royal Society was not prompted by 'mean, selfish, or sordid motives'; 'the interests of the people at large were alone consulted'. This was stretching the truth and was no justification for mutilating Lanne but showed some contrition. While Agnew's motives might have been pure, the same cannot be assumed of Morton Allport, who later sent Aboriginal skeletons to European collectors. ${ }^{103}$

Tasmanian attitudes to the claims of 'science' were more sceptical than the most recent commentator on the Lanne affair has suggested. ${ }^{104}$ Generally, Tasmanians attached 'small importance' to science, especially its more esoteric and non-utilitarian branches, and did not condone the actions of 'the demented votaries of science'. ${ }^{105} \mathrm{As}$ 'Humanitas' put it, 'they who worship at the shrine of science do little honour to their

99. M, 9 March 1869.

100. Examiner, 13 March 1869.

101. Winter 1972, pp. 6, 21, 64 .

102. EM, 20 March 1869.

103. Davis 1874, p. 5 .

104. Cove 1995, pp. 52-3, 177, 183.

105. Examiner, 10 April 1869 and see the article 'The Value of Science in Tasmania' in ibid, 9 July 1869. 
goddess, when they choose the dark hours of midnight and the place of graves for performing their orgies'. ${ }^{106}$ 'Job Muggs' was close to the mark when he suggested that 'morbid Curiosity' rather than science motivated the mutilators and body-snatchers. ${ }^{107}$ Equally curious and worthy of preservation, argued 'Job Muggs' was the effect of civilisation on the Aboriginals. The museum should therefore also contain 'the skeleton of the first White man who murdered a Black one and debauched his Gin, and the first bullet and bayonet that sped the messages of death to the vitals of a native heathen, or the first piece of manufactured hemp that choked a poor wretch convicted of crimes he was ignorant of until taught them by the example of his European instructors'. Here satire was used effectively to highlight how colonial museums provided one-sided views of relations between colonists and Aboriginals and shaped perceptions of the colony's history.

The loose management of the hospital received its share of criticism. Evidence given to the various enquiries revealed that dead bodies left at the hospital and not claimed by family or friends were dissected by medical students. ${ }^{108}$ Unless the management was improved, wrote the Mercury, 'public confidence' in the hospital would be lost and it might have to close. ${ }^{109}$ People did not want dead bodies 'treated with an indignity from which, applied to a dog, a sensitive mind would revolt'. The keys to the dead-house were available to all the honorary medical officers. Most 'freely exercised' their right of access and rumour had it that 'strange things had been done before this in that same dead-house'. The Mercury suggested that one hospital official should be responsible for ensuring bodies in the dead-house were respected. The honorary medical officers must be refused permission 'to hack and hew bodies of those who die in the Hospital for their own amusement, or the instruction of their pupils'. Stokell was severely criticised for incompetence. He should have closed or sealed the dead-house and asked for a warder or territorial policeman to guard the door. ${ }^{110}$ Stokell was also at fault for cutting off Lanne's hands and feet. His future at the hospital was in doubt.

But the more serious offence was cutting off Lanne's head and all the evidence pointed to William Crowther and his son as the culprits. The Hospital Board, at the behest of the government, had little choice but to suspend them. As Crowther was about to stand for election to the Legislative Council seat of Hobart as an opponent of the Dry Government, the timing was politically convenient. This made the Hospital Board, wrote the Tasmanian Times, 'the cats-paw of the Government in damaging a political opponent and creating political capital out of the gross neglect of duty' by Stokell. ${ }^{111}$ As the Hospital Board also contained 'at least three personal enemies' of Crowther, it willingly supported the government's decision. Since the mid-1860s, Crowther had agitated against the Dry Government's policy, supported by the Hospital Board, of inadequately funding the hospital and keeping it as a pauper institution. ${ }^{112}$ Crowther wanted it to become 'an independent charity supported by patients' fees as

106. TT, 22 March 1869.

107. Tasmanian Catholic Standard, 20 March 1869.

108. EM, 12 March 1869.

109. $M, 9$ March 1869.

110. TT, 9 March 1869.

111. ibid, 12 and 13 March 1869.

112. Rimmer 1981, pp. 96-7. 
well as by philanthropic subscribers'. Crowther irritated the board by regularly giving prescriptions to working men who obtained free medicine from the hospital's dispensary.

Crowther's defence in a letter to Dry on 8 March-subsequently published in the press-damned him further in many people's eyes. ${ }^{113} \mathrm{He}$ accused Stokell of cutting off Lanne's head, feet, and hands 'for the purpose of creating a sensation'. Crowther thought the proceedings against him savoured 'too forcibly of the Star Chamber and the Inquisition'. The whole affair reeked of 'political bias and intrigue'. Nowhere in his letter did Crowther deny that he was an accessory to the act, that he was directly or indirectly involved, or that he had any knowledge of who was involved. The Mercury, owned by Crowther's enemy John Davies, discounted Crowther's claim of political bias. ${ }^{114}$ Crowther was not a political power and no political grouping would have arranged 'such an outrage on decency, and then laid the charge of it on the Doctor to injure him politically'.

Crowther had made a tactical error by accusing Stokell. Logically it made little sense. Stokell had more to gain by keeping the decapitation secret than by making it public, as it exposed his failure to take proper precautions to guard Lanne's body. The Royal Society had already been promised the corpse and Stokell had no reason to remove Lanne's head. More importantly, argued a correspondent to the Evening Mail, it was morally wrong to accuse another, whom you know to be innocent, of your own crime; it was wrong to 'bear false witness against thy neighbour' ${ }^{115}$ According to ' $N$ ', disobeying Dry's orders did not involve 'great moral delinquency' and Crowther's 'honour might have been unimpeached had the matter ended there'. ${ }^{116}$ But, in a 'base and most cowardly' act, Crowther attempted to fix the blame on the innocent Stokell, whose career might have been destroyed. ' $N$ ' conceded that Stokell's conduct was not blameless but he had the honesty to admit that he had cut off Lanne's hands and feet and removed the body from the grave. Also reprehensible was Crowther's failure to protect his son from his 'most revolting' conduct. Crowther, his enemies rightly declared, was a man without scruples.

The affair did not divert Crowther from contesting the seat of Hobart in the Legislative Council. On 18 March his supporters reaffirmed their loyalty at a public meeting. ${ }^{117}$ One of his supporters said the election was not intended 'to prove who had the black man's head, but rather to show how the white man might live'. When Crowther was elected, 'not a word more would be heard about King Billy'. Crowther was opposed by Alfred Crisp, who was backed by prominent members of the Royal Society and who were Crowther's 'most active and bitter' detractors. ${ }^{118}$ Members of the Royal Society Council included T.D. Chapman, Treasurer in the Dry Government, and Alfred Kennerley, Chairman of the Hospital Board. John Davies, Dry's Attorney-General W.L. Dobson, and Alderman David Lewis of the Hospital Board were fellows of the Royal

113. EM, 10 March 1869.

114. $M, 12$ March 1869.

115. EM, 21 April 1869, letter by 'Spectator'.

116. M, 19 March 1869.

117. TT, 19 March 1869.

118. CC, 27 March 1869; TT, 20 March 1869. 
Society. ${ }^{119}$ Despite this opposition, Crowther won easily. In his victory speech he attacked the press and his opponents for making 'political capital' out of 'King Billy's head' and said he had lost no sleep over the accusations made against him. ${ }^{120}$ The Examiner was struck by Crowther's callous disregard of his wrongdoing. ${ }^{121}$ Notwithstanding the election result, the Examiner believed that 'the great majority' of Tasmanians viewed Crowther's action with 'the greatest repugnance' and an offence against 'honour, morality, and common decency'. But the Dry Government deserved censure too. It did not approach the affair impartially or seek to apportion blame and punishment where appropriate. The government had advice from its own legal officers that Crowther had committed a misdemeanour by taking Lanne's head and, if convicted, was liable for imprisonment or fine. ${ }^{122}$ Dry did not want a quick trial in a neutral court. He tried to injure a political opponent by prolonging the affair and failed badly. ${ }^{123}$

Shortly after his election Crowther had another reason to gloat. The Royal College of Surgeons in London awarded him a 'gold medal' for his 'valuable and numerous contributions' to their Hunterian museum. ${ }^{124}$ This honour had been bestowed on only four others. But, despite strenuous efforts and Dry's unexpected death in August 1869, Crowther was not immediately reinstated as an honorary medical officer. In September 1869 , at a public meeting, Crowther's supporters presented him with a purse of 240 sovereigns as thanks for his 'unremitting and disinterested services' in attending without charge 'the suffering poor' of Hobart Town. ${ }^{125}$ Harking back to the colony's convict origins, Crowther said that 'the ruffianism and high-handed injustice' with which he had been excluded from the hospital 'could not have occurred, or been tolerated, in any other place on the surface of the globe than Tasmania'. That was special pleading. Crowther's dismissal was the minimum punishment for disobeying Dry's orders and well within the rights of the government to impose.

In seeking revenge, Crowther resorted to more than slurs on Tasmanian society. On 1 October, this 'apostle' of the Railway and Progress Association, vented his 'personal antipathy' against the James Milne Wilson Government by voting with the antirailway lobby against the Main Line Railway Bill. ${ }^{126}$ The Mercury noted that 'KING BILLY again plays an important part in our public affairs, and Tasmania jeopardises its Railway' ${ }^{127}$ In early 1870, Crowther was no doubt elated at the news that Stokell's probationary period as house surgeon had ended and that he would not be reappointed. ${ }^{128}$ The Wilson Government intended to appoint an experienced full-time senior administrator to reorganise the management of the hospital and Stokell was considered too inexperienced for such an important position. Equally, it could have been punishment

119. Papers and Proceedings of the Royal Society of Tasmania 1869, pp. 69-74.

120. EM, 23 March 1869.

121. Examiner, 27 March 1869.

122. EM, 17 April 1869.

123. AOTCSD 7/23/127, Dowdell and Fisher to Dry, 26 May 1869; TT, 21 April 1869.

124. Examiner, 20 April 1869.

125. TT, 28 September 1869.

126. M, 2 October 1869.

127. ibid.

128. Rimmer 1981, pp. 97-8; Historical Committee of the National Trust 1966, p.181. 
for failing to protect Lanne's body. Stokell later moved to Campbell Town in Northern Tasmania, where he died in obscurity in 1878.

In the 1870 s Crowther forged a successful political career. In 1876-77 he was minister without portfolio in Thomas Reibey's government and in January 1877 Reibey reinstated him as an honorary medical officer. ${ }^{129}$ From December 1878 to October 1879 Crowther was Premier, the first doctor to hold that office. ${ }^{130}$ He remained in politics until his death in April 1885. Crowther's memory was perpetuated by an imposing statue financed by public subscription and erected in Franklin Square, in January 1889.131

No such memorial was ever erected for Lanne. In a sense, though, Lanne did leave a memorial behind. In August 1869, William Dobson, Attorney-General in the Wilson Government, introduced the Anatomy Bill to regulate the practice of anatomy. ${ }^{132}$ Based on the English Anatomy Act 1832, this rendered 'lawful a system which for many years was unlawful', said Dobson. It allowed legally qualified doctors and students licensed by the Colonial Secretary to practice anatomy, provided the relatives or executor of the deceased agreed and provided the deceased did not express his opposition to anatomical examination. A breach of the statute would result in three months imprisonment or a $€ 50$ fine. During debate on the bill in the House of Assembly, the lawyer W.R. Giblin suggested that, to make regulation 'as complete as possible, and provide for every emergency', the bill should make removing a body from a cemetery after burial a misdemeanour. As the common law made an offender liable for two years imprisonment for criminal misdemeanour, Dobson saw no necessity for taking up Giblin's suggestion. But thanks to Lanne, the Anatomy Act 1869 protected future dead bodies from indiscriminate dissection in hospitals.

\section{Concluding remarks}

Scientists were desperate to study Lanne's skeleton for what it could reveal about human evolution. But we have no evidence to show that any studies of Lanne's skeleton or skull were ever carried out. It seems that his body parts were ultimately disposed of in various ways. According to Ryan, Stokell made 'a tobacco pouch' out of part of Lanne's skin, his fellow Tasmanian scientists grabbed other body parts (the ears, the nose, and part of one arm), and his arms and feet were kept at the museum, but Ryan seems to have no compelling evidence to support these assertions. ${ }^{133}$ Plomley notes that the curator of the museum, Morton Allport, sent five skeletons to Europe between 1870 and 1875 but does not indicate whether Lanne's skeleton was one of them. ${ }^{134}$

As for Lanne's skull, we can do nothing but speculate, as the leading protagonists appear not to have left any diaries or letters divulging its ultimate resting place. We do, however, have the recollections of Dr. Thomas Christie Smart, an Alderman and an honorary medical officer at the Hobart General Hospital in 1869. According to Smart,

129. Rimmer 1981, p. 105.

130. Crowther 1969, p. 502.

131. ibid.

132. $M, 1,8,9$ September 1869 .

133. Ryan 1981, p. 217.

134. Plomley 1962, p. 6. 
Crowther kept the skull at his house until he decided what to do with it. ${ }^{135}$ Some months after the decapitation, Crowther told Smart that an islander from a whaling ship, was 'very ill in a house on the old wharf'. Crowther did not expect the man to survive and suggested to Smart that, if the body was sent to the hospital, 'no enquiries should be made by the authorities after his death'. Wise to Crowther's intentions, Smart thought it best that the man not be sent to the hospital, 'as he would certainly make no promises to shut his eyes' to any interference with the body. In the event, the man died and the body disappeared. Smart suggested that Crowther took the body, using the skeleton as 'a proper setting to the stolen head'.

According to Smart, it was 'well known that the supposed skeleton and head of King Billy' was sent by Crowther to the Royal College of Surgeons in London. ${ }^{136}$ In return, Crowther was made an honorary fellow in 1874. In 1887 Agnew also noted that the skull was sent to the Royal College of Surgeons, although, perhaps to vex his rivals for the skull, he asserted that Lanne was not a 'pure-blooded' Tasmanian Aboriginal, claiming that he had the blood of a New South Wales Aboriginal. ${ }^{137}$ Some evidence casts doubt that the skull was sent to London, as an analysis of catalogues of skeletons and skulls donated to the Royal College of Surgeons did not find any donations from Crowther. ${ }^{138}$ Pybus stretches credulity by imaginatively suggesting that the skull did not reach London because sailors, irritated by the smell, threw it overboard. ${ }^{139}$ Another possibility is that Lanne's skull was sent to the University of Edinburgh. After Crowther died, a skull found in his collection was donated to Edinburgh, his son Dr. E.M. Crowther believing it to be Lanne's. ${ }^{140}$ Recent investigations by scientists at the University of Edinburgh revealed that the skull in the university's collection was not Lanne's. ${ }^{141}$ It is difficult to prove beyond doubt that Lanne's skull was sent to the Royal College of Surgeons by Crowther. The College's collection was destroyed by German bombers in World War Two, and Plomley's later study of contemporary correspondence and catalogues sheds no light on the skull's fate. ${ }^{142}$ Given Crowther's efforts to secure Lanne's skull for the Royal College of Surgeons, it was ironical that in 1881 the curator of the Hunterian Museum, Sir William Flower, publicly 'questioned the value of craniology' in determining scientifically the place of different races in human evolution. 143

If it cannot be said that science made good use of Lanne's skeleton, did Tasmanians learn anything from the Lanne affair when his wife Truganini, supposedly the last 'full-blooded' Tasmanian Aboriginal, died in $1876 ?^{144}$ In the short term, the answer is yes. In 1876 the Premier was Alfred Kennerley and his government politely but firmly

135. UT Walker papers, W9/C4/1 (12), Walker to Ling Roth, ? 1896.

136. ibid.

137. Agnew 1888, p.479.

138. Plomley 1962, p. 6.

139. Pybus 1992, p. 169.

140. Plomley 1962, p. 8.

141. Murray 1993, p. 516.

142. Plomley 1962, p. 6.

143. Lorimer 1988, p.420.

144. According to Ryan, the last 'full-blooded' Tasmanian Aboriginal to die was a woman called Suke, who died on Kangaroo Island in 1888, see Ryan 1981, p.220. 
rejected two bids by the Royal Society for Truganini's body, expressing a desire 'to prevent the recurrence of the unseemly proceedings' which occurred after Lanne's death. ${ }^{145}$ This time precautions were taken. At the hospital, the body was guarded by a constable. ${ }^{146}$ To foil the chances of body-snatchers, the government departed from the funeral program announced in the press. Instead of burying the body at noon on 11 May, the government authorised the Superintendent of the Cascades Gaol, Superintendent A.H. Boyd, to remove the body from the hospital at 11.00 p.m. on 10 May. Next day, Truganini was buried in a grave not far from the front door of the chapel behind the walls of the gaol and secure from the machinations of body-snatchers. Boyd was instructed not to permit the removal of Truganini's remains from the grave 'without a written Order from the Governor-in-Council', ${ }^{147}$

Ultimately the scientists triumphed. In December 1878 the Royal Society secured control of Truganini's skeleton from the government of W.R. Giblin, a strange decision by that sane and brilliant man, on the condition that it would not be 'exposed to public view but be decently deposited in a secure resting place where it may be accessible, by special permission, to scientific men for scientific purposes' ${ }^{\prime 148}$ Did Giblin know that he was about to lose office to William Crowther and act to frustrate his successor? Whatever the reason, the condition was broken in 1904 when the skeleton was placed on public display in the local museum, where it remained until $1947 .{ }^{149}$ Despite many lofty pronouncements of its significance, Truganini's body, like Lanne's, was never the subject of close scientific investigation. ${ }^{150}$ But unlike Lanne, Truganini's body was not mutilated. Her body was cremated and, true to her wishes, on 1 May 1976 the ashes were scattered over D'Entrecasteaux Channel, safe forever from the demands of ambitious and unscrupulous scientists. ${ }^{151}$

\section{Acknowledgments}

This article was first published in Australian Cultural History, no. 16, 1997-8, pp. 18-44. I thank the editor David Walker for allowing this revised version to be republished here. I also thank two referees and Michael Roe for comments on earlier drafts.

\section{References}

Agnew, James 1888, 'The Last of the Tasmanians', Proceedings of the Australasian Association for the Advancement of Science, vol. 1, pp. 478-481.

Allport, Morton, Personal papers, Allport Library, State Library of Tasmania.

Australian Joint Copying Project, Colonial Office series, CO 280.

Backhouse Walker, James Personal papers, University of Tasmania Archives.

Barnard, James 1890, 'Aborigines of Tasmania', Proceedings of the Australasian Association for the Advancement of Science, vol.2, pp. 597-611.

145. UT RSA/B/16, Gilmore to Agnew, 10 May 1876, 19 July 1876.

146. $M, 12$ May 1876 .

147. UT RSA/B/16, Gilmore to Agnew, 19 July 1876.

148. Ibid, Moore to Agnew, 6 December 1878.

149. Ryan 1981, p. 220.

150. Plomley 1987, p. 191; Cove 1995, pp. 142-3.

151. Ryan 1981, p. 220. 
Bolger, Peter 1973, Hobart Town, Canberra.

Bonwick, James 1870, The Last of the Tasmanians; or, The Black War of Van Diemen's Land, London (Australiana Facsimilie Editions No. 87, Libraries Board of South Australia, 1969).

Chamberlain, Susan 1988, The Hobart Whaling Industry, 1830 to 1900 , PhD thesis, LaTrobe University, Bundoora.

Colonial Secretaries Office, General Correspondence, CSD 4/77/231, 7/23/127, 7/24/ 150, Archives Office of Tasmania.

Cornwall Chronicle newspaper, Launceston.

Cove, John J. 1995, What the Bones Say: Tasmanian Aborigines, Science, and Domination, Ottawa.

Critic newspaper, Hobart.

Crowther, W.E.L.H. 1969, 'William Lodewyk Crowther (1817-1885)', Australian Dictionary of Biography, vol. 3, pp. 501-503.

- 1974, 'The Final Phase of the Extinct Tasmanian Race 1847-1876', Records of the Queen Victoria Museum, no. 49, pp. 1-34.

Davis, Joseph Barnard 1874, On the Osteology and Pecularities of the Tasmanians, A Race of Man Recently Become Extinct, Haarlem.

Ellis, Vivienne Rae 1976, Trucanini: Queen or Traitor?, Hobart.

Evening Mail newspaper, Hobart Town.

Examiner newspaper, Launceston.

Gaylor, Charles, Correspondence file, Archives Office of Tasmania.

Governor's Office, Letterbooks of Confidential Despatches sent to the Secretary of State, GO 27/1, Archives Office of Tasmania.

Historical Committee of the National Trust 1966, Campbell Town, Tasmania: History and Centenary of Municipal Government, Campbell Town.

Leader newspaper, Hobart Town.

Lorimer, Douglas 1988, 'Theoretical Racism in Late-Victorian Anthropology, 1870-1900', Victorian Studies, vol. 31, pp. 405-430.

MacLeod, Roy 1988, 'Organizing Science under the Southern Cross' in The Commonwealth of Science: ANZAAS and the Scientific Enterprise in Australasia 1888-1988, ed. Roy MacLeod, Melbourne, pp. 19-39.

Mercury newspaper, Hobart Town.

Murray, Tim 1993, 'The Childhood of William Lanne: Contact Archaeology and Aboriginality in Tasmania', Antiquity, vol. 67, pp. 504-17.

Petrow, Stefan 1993, 'God's Neglected Acres: Cemeteries in Tasmania 1803-1992', Public History Review, vol.2, pp. 144-67.

Plomley, Norman James Brian 1962, 'A List of Tasmanian Aboriginal Material in Collections in Europe', Records of the Queen Victoria Museum, new series, no. 15, 2-18.

— (ed.) 1987, Weep in Silence: A History of the Flinders Island Aboriginal Settlement, with the Flinders Island Journal of George Augustus Robinson 1835-1839 , Hobart.

Pybus, Cassandra 1992, Community of Thieves, Port Melbourne. 
Register of children admitted and discharged from the male and female Orphan School

1828-1863, SWD 28, Archives Office of Tasmania.

Reynolds, Henry 1987, Frontier: Aborigines, Settlers, and Land, Sydney.

1995, Fate of a Free People, Ringwood.

Richardson, Ruth 1987, Death, Dissection and the Destitute, London.

Rimmer, W.G. 1981, Portrait of a Hospital: The Royal Hobart, Hobart.

Royal Society of Tasmania, Council Minute Books, RSA/A/4, RSA/B/16 University of Tasmania Archives.

- Annual Report 1869. Proceedings 1869, pp. 71-4.

Rumney, William, Correspondence file, Archives Office of Tasmania.

Ryan, Lyndall 1981, The Aboriginal Tasmanians, St. Lucia.

1985, 'Extinction Theorists and Tasmanian Aborigines: Apologists for an Extemination Policy' in The Future of Former Foragers in Australia and Southern Africa, eds. Carmel Schire and Robert Gordon, Cambridge, pp. 47-54.

Stocking, George W. 1987, Victorian Anthropology, New York.

Tasmanian Catholic Standard newspaper, Hobart Town.

Tasmanian Times newspaper, Hobart Town.

Turnbull, Paul 1991, "Ramsay's Regime": The Australian Museum and the Procurement of Aboriginal Bodies, c.1874-1900', Aboriginal History, vol. 15, pp. 108-121.

- 1994, 'To What Strange Uses: The Procurement and Use of Aboriginal Peoples' Bodies in Early Colonial Australia', Voices, vol. 4, pp. 5-20.

Winter, Gillian 1972, "For...the Advancement of Science": The Royal Society of Tasmania 1843-1885, B.A. Hons. thesis, University of Tasmania, Hobart. 